Schukajlow, Stanislaw; Rakoczy, Katrin; Pekrun, Reinhard

\title{
Emotions and motivation in mathematics education. Theoretical considerations and empirical contributions
}

formal und inhaltlich überarbeitete Version der Originalveröffentlichung in:

formally and content revised edition of the original source in:

ZDM : the international journal on mathematics education 49 (2017) 3, S. 307-322

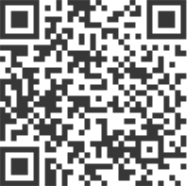

Bitte verwenden Sie in der Quellenangabe folgende URN oder DOI /

Please use the following URN or DOI for reference:

urn:nbn:de:0111-pedocs-158593

10.25656/01:15859

https://nbn-resolving.org/urn:nbn:de:0111-pedocs-158593

https://doi.org/10.25656/01:15859

\section{Nutzungsbedingungen}

Gewährt wird ein nicht exklusives, nicht übertragbares, persönliches und beschränktes Recht auf Nutzung dieses Dokuments. Dieses Dokument ist ausschließlich für den persönlichen, nicht-kommerziellen Gebrauch bestimmt. Die Nutzung stellt keine Übertragung des Eigentumsrechts an diesem Dokument dar und gilt vorbehaltlich der folgenden Einschränkungen Auf sämtlichen Kopien dieses Dokuments müssen alle Urheberrechtshinweise und sonstigen Hinweise auf gesetzlichen Schutz beibehalten werden. Sie dürfen dieses Dokument nicht in irgendeiner Weise abändern, noch dürfen Sie dieses Dokument für öffentliche oder kommerzielle Zwecke vervielfältigen, öffentlich ausstellen, aufführen, vertreiben oder anderweitig nutzen.

Mit der Verwendung dieses Dokuments erkennen Sie die Nutzungsbedingungen an.

\section{Terms of use}

We grant a non-exclusive, non-transferable, individual and limited right to using this document

This document is solely intended for your personal, non-commercial use. Use of this document does not include any transfer of property rights and it is conditional to the following limitations: All of the copies of this documents must retain all copyright information and other information regarding legal protection. You are not allowed to alter this document in any way, to copy it for public or commercial purposes, to exhibit the document in public, to perform, distribute or otherwise use the document in public.

By using this particular document, you accept the above-stated conditions of use.

\section{Kontakt / Contact:}

peDOcs

DIPF | Leibniz-Institut für Bildungsforschung und Bildungsinformation Informationszentrum (IZ) Bildung

E-Mail: pedocs@dipf.de

Internet: www.pedocs.de 


\title{
Emotions and motivation in mathematics education: Theoretical considerations and empirical contributions
}

\author{
S. Schukajlow ${ }^{1}$, K. Rakoczy ${ }^{2}$, and R. Pekrun ${ }^{3}$ \\ ${ }^{1}$ Department of Mathematics, University of Münster, Fliednerstraße 21, 48149 Münster, \\ Germany \\ ${ }^{2}$ Center for Research on Educational Quality and Evaluation, German Institute for \\ International Educational Research, Schloßstraße 29, 60486 Frankfurt am Main, Germany \\ ${ }^{3}$ Department of Psychology, University of Munich, Leopoldstrasse 13, 80802 Munich, \\ Germany, and Institute for Positive Psychology and Education, Australian Catholic \\ University, Sydney, Australia
}

\begin{abstract}
Emotions and motivation are important prerequisites, mediators, and outcomes of learning and achievement. In this article, we first review major theoretical approaches and empirical findings in research on students' emotions and motivation in mathematics, including a discussion of how classroom instruction can support emotions and motivation. Based on this review, we encourage researchers from mathematics education and other disciplines of educational research to combine their efforts. Second, we provide an overview of the contributions in this special issue, most of which reflect such a combination of efforts by considering perspectives from both mathematics education and other fields of educational research. Finally, we consider the neglect of intervention studies and outline directions for future research. We identify intervention studies that target emotions and motivation as one promising but so far underrepresented line of research in mathematics education and review results from existing intervention studies. For future research, we suggest that researchers should implement fine-grained concepts, assessment instruments, theoretical hypotheses, and methods of analysis tailored to the specific features of the mathematical domain to adequately investigate students' emotions and motivation in this domain.
\end{abstract}

\section{Introduction}

In his seminal book on mathematical problem solving, G. Pólya wrote as follows:

Your problem may be modest; but if it challenges your curiosity and brings into play your inventive faculties, and if you solve it by your own means, you may experience the tension and enjoy the triumph of discovery. ... If he [the teacher] fills his allotted time with drilling his students in routine operations, he kills their interest... (Pólya 1945, p. V)

This quotation demonstrates that emotions and motivation were assumed to be important for the learning and teaching early in the development of mathematics education. Using Pólya's observation as a starting point, we aim to discuss the following questions: What is the role of emotions and motivation in research on mathematics education now, more than 70 years after Pólya's statement? How are emotions and motivation conceptualized and theoretically grounded? What is the specific contribution of this special issue to research on emotions and motivation? Finally, which interventions promise to support a positive emotional and motivational development, and what are important directions for future research?

\section{Trends in research on emotions and motivation in mathematics education}

We have observed an increased interest in emotions and motivation in mathematics education in the last decade, which is reflected in the growing number of participants attending the Working Group "Affect and Mathematical Thinking" at the CERME- 
Conferences: "[...] we had more papers both submitted and presented than ever before." (Di Martino et al. 2015). In order to validate our impression, we analyzed papers published from 2002 to 2014 in the journals Journal for Research in Mathematics Education and Educational Studies in Mathematics, which are two of the most influential journals in the field (see e.g., Toerner and Arzarello 2012 or Web of Science, Social Sciences Citation Index, Journal Citation Reports). However, the analysis was performed for two journals only, thus the results should be interpreted with caution. Altogether, $8 \%$ of the publications in 2002 referred to emotions or motivation (among other content). The figure rose to $9 \%$ in $2005,12 \%$ in $2008,14 \%$ in 2011 , and $17 \%$ in 2014 . However, the number of research contributions on emotions still remained very small (less than $4 \%$ in 2014).

Most of these papers reported case studies that reflected the efforts of researchers in mathematics education to carry out in-depth analyses of emotional and motivational processes during teaching and learning. Very few studies published in this period tested theory-derived hypotheses or allowed generalization beyond the analyzed cases. The exclusive use of case studies is not in line with a widely accepted consensus (at least since 2009) among researchers in mathematics education that both descriptive and experimental studies as well as quantitative, qualitative, and mixed methods are important for substantial progress in this field as a scientific domain (Battista et al. 2009).

In the same period of time, researchers from various fields of educational research more generally responded to calls from the early 2000s (Schutz and Lanehart 2002) and 1990s (Pintrich 1991) to consider emotions and motivation. To examine development in educational research more generally, we analyzed papers published in Learning and Instruction, which was one of the journals with the highest impact factors in the category "Education and Educational Research" during this time (Web of Science, Social Sciences Citation Index, Journal Citation Reports). About $50 \%$ of all papers published in "Learning and Instruction" dealt with these topics in 2005, 2008, 2011, and 2014, with a clear focus on testing hypotheses derived from theoretical assumptions.

Only a few contributions (e.g., one of 26 contributions addressing emotions and motivation in 2014), however, reported on emotions and motivation in the domain of mathematics in this journal. The specifics of the content of tasks, moreover, were often neglected in educational research (Volet 2001), a practice that can reduce the ecological validity and practical relevance of studies. One indicator of "neglecting the content" is when a general description of the tasks is given but sample tasks are not provided. This practice stands in contrast to the often more detailed description of experimental procedures and questionnaires. Neglecting the content implies that important features of tasks and their influence on emotion, motivation, and learning are not taken into account.

In research carried out in the domain of mathematics education, the type of problem has been identified as an important factor that influences emotions and motivation over and above the effects of task difficulty. For example, the effects of "dressing up" intramathematical problems (i.e., converting intra-mathematical problems into word problems) on motivation and emotions have widely been discussed in mathematics education, although they have not yet been sufficiently empirically clarified (Beswick 2011; Schukajlow et al. 2012). One contribution in this special issue reports that students' interest differed between problems with a connection to reality ("dressed up" word problems and modelling problems) and problems without a connection to reality (intra-mathematical problems) when controlling for task difficulty (Rellensmann and Schukajlow 2017). As students' emotions such as enjoyment and boredom are related to their interest (Pekrun et al. 2011; Tulis and Ainley 2011; Schukajlow and Rakoczy 2016; Winberg et al. 2014), similar differences can also be expected for students' emotions. Taken together, we argue that task contents and domains should be considered to a greater extent in research on emotions and motivation in 
education, as emotions and motivation have been shown to be content-specific (Rakoczy 2008; Schukajlow et al. 2012) and domain-specific (Goetz et al. 2007).

\subsection{Early definition of emotions and motivation in mathematics education}

Modern research on emotions and motivation in mathematics education probably began with McLeod's (1992) conceptualization of the affective domain. McLeod ordered affective variables along a continuum of intensity and temporal stability, ranging from emotions via attitudes to beliefs. As McLeod used the term, affect included a broad variety of noncognitive constructs (for use of the term affect in emotion research and the affective sciences more broadly, see Pekrun and Linnenbrink-Garcia 2014a). According to McLeod's classification, an intense but unstable emotion (e.g., momentary joy in solving a specific problem) can change into a low-intensity but stable attitude (enjoyment of problem solving). Similarly to attitudes, beliefs (including motivational beliefs) are also thought to arise from emotions.

One strong feature of this system is its simplicity, which allows researchers to sort constructs into one of three categories. However, one problem is that emotions that differ in stability are denoted with different emotion terms (e.g., "joy" vs. "enjoyment") even if the type of emotion is the same. Using terms such as state versus trait emotions (e.g., state enjoyment vs. trait enjoyment) seems better suited to avoiding this problem (see below). Furthermore, recent theorizing and empirical research in the affective domain shows that it is possible to use more fine-grained distinctions of emotional and motivational constructs (e.g., Zan et al. 2006). By analyzing specific emotions such as enjoyment, anxiety, and boredom, or motivational constructs such as situational and individual interest, it is possible to derive more detailed accounts of students' and teachers' affect.

Thus we suggest that there is a need to elaborate upon McLeod's taxonomy and characterize emotional and motivational variables by using more fine-grained affective constructs as proposed in recent research in mathematics education and education more generally (e.g., Hannula 2015; Pekrun 2006). Herein we focus on achievement emotions and motivation (Weiner 1985), both of which are critically important in educational contexts. Achievement emotions and motivation include constructs that are specifically related to learning, its antecedents, and its outcomes.

\subsection{Characteristics of emotions and motivation}

One important characteristic of emotions and motivation is their valence. Most emotional and motivational constructs are characterized by positive or negative valence. For example, enjoyment of mathematics is a positive (i.e., pleasant) emotion, and boredom in mathematics is a negative (i.e., unpleasant) emotion. Many motivational constructs also have valence; for example, interest is considered to have a positive valence (Scherer et al. 2013).

Emotional and motivational constructs vary in their level of temporal stability from variable states to stable traits. If students feel bored while solving a mathematical problem, this is an emotional state; if they are disposed to often being bored while solving mathematical problems, this is an emotional trait. With boredom as an emotional trait, merely thinking about a problem-solving activity can cause boredom, even if students do not know what tasks they will be given to solve in the classroom. In theories of interest, a stable individual interest in mathematics (interest as a trait) emerges from unstable situational interest in specific mathematical problems (interest as a state) (Hidi and Renninger 2006).

Further, it is important to distinguish between objects of emotions or motivation. Such objects can be learning in general, the domain of mathematics, an area of mathematics (e.g., 
algebra), a topic (e.g., Pythagorean theorem), a mathematics-specific activity (e.g., problem solving), or even a specific task (e.g., Monty-Hall-problem) (Schukajlow 2015).

Finally, although emotions and motivation are distinct phenomena, it is important to note that they show conceptual overlap. Emotion theories consider emotion-specific motivational impulses as part of emotion, and motivation theories consider emotions as psychological forces that motivate action (for conceptual similarities and differences between the two constructs, see Pekrun 2006). For example, in conceptions of interest, emotions (specifically, enjoyment) were considered to be an important part of interest (Krapp 2005), and enjoyment during mathematical lessons was found to predict interest in mathematics (Schukajlow and Rakoczy 2016).

\subsection{Achievement emotions}

Different definitions of emotions have emerged from different paradigms, such as Darwinian, Freudian, or cognitive-psychological traditions (Hannula 2015). Today emotions are usually defined as complex phenomena that include affective, cognitive, physiological, motivational, and expressive components (Shuman and Scherer 2014). Some emotion theories propose that there is a fixed number of basic emotions (Ekman 1992; Oatley and Johnson-Laird 1987), whereas other theories group emotions into broader categories such as achievement, epistemic, and social emotions (Pekrun and Stephens 2012). Within the achievement emotions, subgroups include emotions related to achievement activities (activity emotions; e.g., enjoyment or boredom) and emotions related to success and failure outcomes (outcome emotions; e.g., hope for success) (Pekrun 2006).

A number of appraisals such as valence, goal congruency, expectedness, or controllability are assumed to influence human emotions; they can be classified as situational appraisals and appraisals about the self (Scherer et al. 2001). In the control-value theory of achievement emotions (Pekrun 2006), two groups of appraisals are thought to be especially relevant for the arousal of achievement emotions: perceived control over achievement activities and outcomes (e.g., the expectation that putting effort toward learning improves mathematical performance) and the perceived value of these activities and outcomes (e.g., importance of high performance in mathematics).

The contributions in this special issue investigate enjoyment, pride, anxiety, worry, anger, and boredom (Bieg et al. 2017; Buff et al. 2017; Lauermann et al. 2017). Here, we briefly discuss enjoyment, boredom, and worry (or anxiety) and their development during adolescence. These emotions represent different groups of achievement emotions according to the control-value theory (enjoyment: positive activating; worry and anxiety: negative activating; boredom: negative deactivating; Pekrun 2006) and are particularly important in several contributions in the special issue.

Enjoyment is a positive activity emotion and was found to be one of the most frequently reported positive emotions in the context of learning (Pekrun et al. 2002). Enjoyment was found to decrease in adolescence (Pekrun et al. 2007). Boredom is considered a negative activity emotion and is one of the most frequently experienced unpleasant emotions (Pekrun et al. 2010; Goetz et al. 2007). The development of boredom in mathematics at school has rarely been investigated (Ahmed et al. 2013; Nett et al. 2011; Pekrun et al. 2017). One early study in the domain of mathematics showed higher levels of boredom in the eighth grade compared with fifth grade (Larson and Richards 1991). Consistent with this finding, recent longitudinal studies found a significant increase in boredom in school learning from fifth to ninth grade and fifth to seventh grade, respectively (Pekrun et al. 2007, 2017; Vierhaus et al. 2016). Students' worry was investigated as a negative activity emotion in problem solving (Tornare et al. 2015). Traditionally, worry is also conceptualized as a component of students' 
fear and achievement anxiety (Hannula 2006; Lichtenfeld et al. 2012; Pekrun et al. 2002; Gläser-Zikuda et al. 2005). Findings regarding the development of mean levels of anxiety and worry about mathematics during adolescence are mixed. In the cross-sectional study by Wigfield and Meece (1988), mean levels of worry were higher in grade 9 than in grade 6 , whereas they were found to decrease from sixth grade to seventh grade in the longitudinal study by Reuman et. al (1987) and did not change significantly from grade 5 to 9 in the longitudinal study by Pekrun et al. $(2007,2017)$.

Empirical research has also found that emotions in mathematics can profoundly influence learning and achievement. The detrimental effects of mathematical anxiety on students' performance have been researched the most (for an overview, see Chang and Beilock 2016). More recently, researchers have also begun to investigate the effects of emotions other than anxiety. For example, in a longitudinal study of secondary school students' emotions and performance in mathematics, Pekrun et al. (2017) found that positive emotions such as enjoyment had positive effects on students' grades and test scores in mathematics across the school years, whereas negative emotions such as boredom and anxiety had negative effects. Students' performance, in turn, had positive effects on the development of positive emotions and negative effects on negative emotions, suggesting that emotions and performance in mathematics can be linked by virtuous (entailing positive emotions) and vicious (entailing negative emotions) cycles over time.

\subsection{Motivation}

In educational research, a large body of literature on motivation has developed over the past few decades. Motivational theories in education consider cognitive, social, behavioral, and self-regulation perspectives as well as perspectives from self-determination theory (for an overview, see Ryan 2012). Two theoretical approaches are particularly important for motivational processes in the context of (mathematics) education: expectancy-value theories and self-determination theory.

Expectancy-value theories such as Eccles and Wigfield's model of achievement motivation (Eccles [Parson] et al. 1983; Eccles and Wigfield 2002) and Pekrun's (1993) generalized expectancy-value model assume that engagement in a subject, educational choices, and ultimately achievement, are influenced by two sets of beliefs: expectations of success and subjective task value. Value can be further divided into different types of values and costs (Cambria et al. 2017; Wigfield and Eccles 2000). Expectancies for success are stronger predictors of actual academic achievement (Eccles and Wigfield 2002), whereas value beliefs are stronger predictors of engagement and academic career choices (Wigfield and Eccles 2000).

Self-determination theory is a general theoretical framework for the study of human motivation (Ryan and Deci 2002). Intrinsic and different types of extrinsic motivation are distinguished to explain motivated behavior. While intrinsically motivated learners engage in learning activities because of the characteristics of the activity itself, extrinsic motivation refers to the instrumentality of actions for attaining outcomes that are extrinsic to the activity. A central assumption of self-determination theory is that humans have innate psychological needs for competence, autonomy, and social relatedness. People thus strive to experience themselves as competent (e.g., to exercise a visible influence over their environment), to act autonomously (i.e., consistent with their own will), and to relate to other persons socially. The fulfillment of these needs is thought to be accompanied by positive emotional experiences (Ryan and Deci 2002); it enables individuals to develop intrinsic motivation and to attain a more in-depth understanding of learning content, which in turn can contribute to positive achievement outcomes (Vollmeyer and Rheinberg 2005). Social and environmental factors, 
such as performance feedback, are thought to facilitate or undermine motivation and involvement in learning.

While expectancy-value theories focus on cognitive processes to explain engagement, achievement, and choice, as well as emotional processes such as worry (Lauerman et al. 2017), self-determination theory addresses emotional experiences resulting from need satisfaction. Both theoretical approaches explain how personal and situational factors interact in the development of actual motivational processes and dispositions. In the following, we focus on interest, self-efficacy, and self-concept in mathematics as they were investigated in the contributions in this special issue.

Interest is an important motivational construct that has recently gained considerable attention in mathematics education (Carmichael at al. 2017; Liebendörfer and Schukajlow 2017; Rellensmann and Schukajlow 2017; Ufer et al. 2017). Interest represents a person-object relationship and is characterized by engagement and re-engagement with the content (Hidi and Renninger 2006; Krapp 2005). Persons who are interested in mathematics look for situations where they can interact with mathematical content. They read mathematical books, discuss mathematics with others, and solve mathematical problems within and outside of classes. Theories of interest such as Hidi and Renninger's (2006) four-phase model assume that students' individual interest emerges from situational interest, which can be triggered through social or content factors. Students' prior experiences with the object of interest can contribute to interest in mathematics and related subjects. For example, positive experiences with technology can trigger situational interest in the areas of mathematics, if technology contributes to dealing with mathematics (Renninger et al. 2004). Interest in exploring software can induce situational interest in mathematics even in students with only small initial interest (Hidi and Renninger 2006).

Situational interest in mathematics is expected to occur in so-called interest-dense situations, in which students construct their knowledge in social environments and have opportunities to regulate their epistemic process (Bikner-Ahsbahs and Halverscheid 2014). From the perspective of self-determination theory and Krapp's (2005) approach to interest, fulfillment of the basic needs for competence, autonomy, and social-relatedness is assumed to contribute to the development of interest and intrinsic motivation (Deci and Ryan 2000). In mathematics education, the experience of competence was shown to be important for the development of students' interest (Rakoczy et al. 2013; Schukajlow and Krug 2014). Interest in mathematics declines continuously from primary to secondary school (Köller et al. 2001), with a shift in subjective concepts of interest from an emotion-oriented understanding to a cognitive perspective during adolescence (Frenzel et al. 2012).

Self-efficacy and self-concept have often been investigated in education. By contrast, mathematics education has neglected these constructs for many years (Zan et al. 2006). Both motivational constructs refer to perceptions of the self and of activities that are going to be done or were done in the past. Self-efficacy refers to one's expectation to be able to successfully perform a specific task (Bandura 2003); self-concept of ability refers to perceptions of one's competence in a given domain more generally (for similarities and differences between the two constructs, see Bong and Skaalvik 2003). Across cultures, a typical activity in mathematics is working on problems (Hiebert et al. 2003). Mathematical self-efficacy expectations can be assessed by asking questions about the extent to which students feel confident that they will be able to solve a problem or perform well on an upcoming test. Mathematical self-concept refers to the extent to which they feel confident that they can solve mathematical problems and perform well on tests in general.

Mathematical self-concept has been found to have positive effects on students' performance over time. Furthermore, similarly to the reciprocal links with performance for students' 
emotions, performance reciprocally influences the development of students' mathematical self-concept, supporting Marsh's reciprocal effects model of self-concept development (see e.g., Marsh et al. 2016).

Recent studies in mathematics education have also explored connections between selfefficacy and other motivational and cognitive constructs (Pantziara and Philippou 2015; Schukajlow et al. 2012) or examined the impact of interventions on students' self-efficacy (Schukajlow and Krug 2012; Schukajlow et al. 2012; Stylianides and Stylianides 2014). Research on the development of self-efficacy and self-concept in mathematics revealed a decline in these competence beliefs during elementary school and beyond (Jacobs et al. 2002). However, there are also some indications that self-efficacy expectations exhibit stability if the construct is measured in a domain-specific manner and with specific problems (Schunk and Meece 2006).

\subsection{How can instruction support students' emotions and motivation?}

Research on the relationship between teaching and learning has been summarized in numerous reviews and meta-analyses (Lazowski and Hulleman 2016; Savelsbergh et al. 2016; Seidel and Shavelson 2007). Approaches that investigate relations between characteristics of teaching and affective variables in students mainly stem from research on instructional quality (however, typically these approaches have not focused specifically on emotions). In recent years, there has been a growing consensus that three dimensions of instructional quality can be theoretically and empirically distinguished and can be used to organize the complex and multilayered processes that take place during instruction (Klieme et al. 2006; Kunter and Baumert 2006; Lipowsky et al. 2009). Although labeled differently by different authors, these three dimensions comprise cognitive activation, supportive climate, and classroom management (Lipowsky et al. 2009).

In line with the assumption that characteristics of teaching need to be perceived by students to affect learning (Pauli and Reusser 2006), effects on student perceptions should be empirically investigated to explain whether and how these three dimensions can support emotions and motivation. Empirical studies that have done this in mathematics education can be summarized as follows. Observations of successful classroom management in mathematics instruction in secondary school are positively related with students' motivation (Rakoczy 2008) and interest. The actual use of learning opportunities is frequently assessed by measuring students' attention during the lesson (e.g., Campbell et al. 2004). Intervening effects of students' attention on their emotions and motivation in mathematics, however, have not yet been analyzed. Applying self-determination theory, Rakoczy et al. (2007) analyzed whether students' cognitive activity and emotional experiences explained the impact of observed classroom management on motivation and found intervening effects for both variables. Observed cognitive activation, however, did not show an impact on motivational variables in mathematics instruction in a study of secondary school students (Rakoczy 2008). Furthermore, as assessed from an observer perspective, supportive climate as assessed by classroom observation also did not show effects on motivational variables (Campbell et al. 2004; Lipowsky et al. 2009; Rakoczy 2008). Here, the individual perspective is particularly important. Accordingly, written feedback on a mathematics test as a central aspect of supportive climate showed a positive impact on students' interest development when it was perceived as supporting competence and useful for further learning (Rakoczy et al. 2013).

Beyond cognitive activation, supportive behavior, and classroom management, teachers' emotions in mathematics have been found to impact students' emotions. For example, female elementary school teachers' anxiety in mathematics was found to increase their female students' anxiety in this domain (Beilock et al. 2010), and the extent to which 
secondary school teachers enjoyed teaching mathematics had positive effects on how much students enjoyed mathematics (Frenzel et al. 2009).

Pekrun's (2006) control-value theory represents a theoretical framework that explicitly focuses on emotions when analyzing relations between teaching and learning. In this framework, the following facets of learning environments are thought to be important antecedents of students' emotions: (1) cognitive quality of instruction and task demands; (2) motivational and emotional quality; (3) autonomy support; (4) goal structures and social expectations; and (5) feedback on and consequences of achievement. These facets are presumed to have an impact on students' emotions via their control and value appraisals. Thus, specific facets are assumed to influence students' perceptions of control and value, which, in turn, have an impact on students' emotions (Götz et al. 2013).

An important challenge in this approach is to identify what high teaching quality means (see Bieg et al. 2017). Combining control-value theory with findings from the process-product approach (Brophy and Good 1986), Goetz et al. (2013) identified a set of teaching characteristics and assessed them in real-life situations by applying the experience sampling method. Teaching characteristics could be grouped into two dimensions that were shown to be related to emotions: (a) Perceived supportive instruction was positively related to enjoyment and pride, negatively related to anger, helplessness, and boredom, and not related to anxiety; and (b) perceived excessive demands were negatively related to enjoyment and pride and positively related to anxiety, anger, helplessness, and boredom.

\section{Contributions to this special issue}

Given the importance of combining research efforts from mathematics education and general educational research, we invited researchers from both fields of research to contribute to the present special issue. All of the contributions refer to concepts from both mathematics education and general educational research, thus linking these two fields of research. There are three groups of contributions in this special issue. Contributions in the first group analyze emotions and motivation in the individual student, contributions in the second group address the role of contextual variables, and contributions in the third group consider teachers' emotions and motivation.

\subsection{Students' emotions and motivation}

Gómez-Chacón (2017) investigated the emotional state of perplexity, the cognitive and affective appraisals related to it, and their interaction while solving mathematical problems in a sample of undergraduate university students. She referred to Goldin's (2000) model of interaction between the affective and cognitive systems as a framework and applied fuzzy sets in her statistical analysis. Perplexity was found to be closely related to confusion, frustration, and bewilderment. She found no significant correlations between perplexity and cognitive appraisals, such as the perceived ability to predict what is going to happen next during problem solving.

Lauermann et al. (2017) analyzed primary school students' worry in mathematics and reading, using propositions from Eccles and colleagues' expectancy-value theory and Pekrun's control-value theory. One of the main results of correlational and path-analytic modeling was that students' worried more when they gave relatively low ratings with regard to their abilities and their expectations of success in the respective subject but perceived achievement in the domain to be important, suggesting that expectancy and value interacted to generate worry. Further, the authors found that there was a negative indirect effect of parents' valuing of the subject on students' worry and that this effect was mediated by students' perceptions of value. 
Liebendörfer and Schukajlow (2017) conducted a longitudinal study with pre-service teachers to analyze the development of students' interest during the first year at university and the relation between students' belief systems and their interest. Using correlational and regression analysis, the authors tested hypotheses derived from theories of interest and from theories on beliefs about mathematics (Grigutsch et al. 1998). The findings showed that interest remained stable during the first academic year and confirmed the importance of application (but not process, schema, or formalism beliefs) for pre-service teachers' interest.

Rellensmann and Schukajlow (2017) investigated lower secondary school students' interest and future teachers' judgments of students' interest. Theories of interest (Hidi and Renninger 2006) and theories of the cognitive processes required for solving problems with and without a connection to reality (Blum and Leiss 2007) were used as a conceptual framework.

Whereas students' interest did not differ between problems with and without a connection to reality, pre-service teachers were confident that problems with a connection to reality would be more interesting to students. Furthermore, future teachers overrated students' interest in real-world problems and underrated students' interest in intra-mathematical problems. The accuracy of judgments of students' interest was low and varied considerably among future teachers.

Street et al. (2017) developed and successfully evaluated a new questionnaire for measuring facets of students' self-efficacy at different levels of task difficulty, as proposed by Bandura (2003). The questionnaire included items referring to a subsequent national test in mathematics and differentiated between self-efficacy for tasks with low, medium, and high difficulty. Multi-trait multi-method modeling with data from primary and lower secondary school students was used to examine the validity of the instrument. The authors proposed that developing questionnaires for assessing different facets and levels of self-efficacy will expand our view concerning this construct and its relations with other cognitive, emotional, and motivational variables.

Using a sample of university students, Ufer et al. (2017) investigated possible changes in mathematics as an object of interest and changes in related practices (e.g., changes from application in high school to argumentation and proof at university) during the transition from high school to university. The authors referred to the person-object theory of interest (Krapp 2002). Exploratory factor analysis of a newly developed interest questionnaire confirmed the validity of the instrument and offered first evidence for possible changes in the objects of interest (from school to university mathematics) during the first term at university.

\subsection{The role of context variables}

Bieg et al. (2017) used the control-value theory of achievement emotions as a conceptual framework. They employed experience sampling to measure high school students' emotions and found that the teaching method of direct instruction was related to slightly lower positive emotions (enjoyment and pride) and slightly higher boredom in comparison with individual or group work. Moreover, students' control-related appraisals (perceived pace of instruction and choice) partly mediated the effects of teaching methods on emotions.

Buff et al. (2017) used longitudinal data to examine the role of changes in different types of parental support-related behavior for changes in lower secondary school students' enjoyment. Buff et al. derived their study hypotheses from the control-value theory and tested them in a latent change model, which made it possible to examine intraindividual change, which is critically important in order to adequately model human development. The results confirmed positive effects of changes in parental structure (clarity of parents' learning-related expectations) and negative effects of changes in parental control on students' enjoyment. 
Cambria et al. (2017) investigated the big-fish-little-pond effect on self-concept and value in secondary school students. This effect draws on social comparison theory and is based on the assumption that equally able students have lower expectations of success in a highachieving classroom than in a low-achieving classroom, due to reduced chances to perform well relatively to others when surrounded by high achievers. Using multi-level structural equation modeling, the big-fish-little-pond effect was confirmed for students' self-concept, utility value, intrinsic/attainment value, and cost. Controlling for individual achievement, students from high-achieving classes had lower self-concept and values in mathematics than students from low-achieving classes.

Carmichael et al. (2017) linked teachers' and students' perceptions in an investigation of the relation between teachers' enthusiasm and students' interest. They referred to achievement goal theory (Dweck and Elliott 1983) and interest theories and used multilevel structural equation modeling. On the student level, the findings confirmed a positive relation between students' perceptions of their teachers' enthusiasm for teaching mathematics and students' interest, mediated via students' perceptions of a classroom mastery environment. On the class level, however, enthusiasm for mathematics as a subject reported by teachers was negatively related to students' interest, indicating that it is important to distinguish between enthusiasm for mathematics and enthusiasm for teaching mathematics.

\subsection{Teachers' emotions and motivation}

Jacob et al. (2017) aimed to clarify teachers' appraisals of success that are assumed to be important sources of teachers' emotions (in addition to failure experiences; Frenzel 2014). The analysis of teachers' responses to an open-ended questionnaire about perceived criteria for success in teaching mathematics revealed six categories: (1) students' mathematics skills, (2) students' engagement, (3) students' social skills, (4) cognitive activation in instruction and structured presentation of the learning content, (5) structured organization of the learning environment, and (6) positive feedback from external sources (e.g., supervisors and parents).

Schütze et al. (2017) reported results of an intervention study in which they investigated effects of teachers' training in formative assessment on their feedback practices.

Furthermore, the authors aimed to clarify the role of self-efficacy as a moderator of the hypothesized effects. The study was based on theoretical considerations of formative assessment and used path analytic modeling. The results confirmed that teachers' training in formative assessment resulted in higher levels of declarative feedback knowledge, and that declarative feedback knowledge, in turn, was positively related to the ability to generate feedback for students in a test situation. This indirect effect was moderated by teachers' selfefficacy expectations.

\section{Future directions: intervention studies and open research questions}

Only one contribution in this special issue reported on an intervention study implemented in the classroom (Schütze et al., 2017), whereas the other contributions were based on crosssectional or longitudinal data from teaching and learning as they exist in today's classrooms. The low number of contributions that report intervention studies in this special issue reflects the present state of research in mathematics education. Clearly, more intervention research targeting students' emotions and motivation in mathematics is needed to derive evidencebased recommendations for educational practice. In this section, we provide an overview of existing intervention studies in this field and provide directions for future research.

\subsection{Intervention studies: an overview}


Although cross-sectional and longitudinal studies can render profound insights into the nature of affect and its development, a more comprehensive evaluation of the effectiveness of instruction requires intervention studies. Intervention studies make it possible to experimentally examine effects of instruction on outcome variables such as emotions or motivation. Regardless of their critical importance for scientific progress and several calls for more intervention studies, intervention research targeting emotions and motivation in education has been slow to emerge (Pekrun and Linnenbrink-Garcia 2014b). Educational intervention research has been described as having generally declined during the past two decades (Robinson et al. 2007), and emotional/motivational research is no exception (Lazowski and Hulleman 2016).

Furthermore, the analysis of intervention studies targeting emotions/motivation identified by Lazowski and Hulleman (2016) revealed that most of these studies were carried out in reading (e.g., Guthrie et al. 2006), writing (e.g., Sherman et al. 2013), or science (e.g., Feng and Tuan 2005). A few studies focused on the effects of interventions on grades in multiple domains (e.g., Ruthig et al. 2004), but interventions that were specifically designed for mathematics were neglected. In research on mathematics education, only a few intervention studies exist that investigated the impact of instruction on affect (Achmetli et al. 2014; Marcou and Lerman 2007; Schukajlow et al. 2012; Schukajlow and Krug 2014; Tarim and Akdeniz 2008). One reason for the small number of intervention studies targeting emotions and motivation is that at the beginning of the last decade, researchers in mathematics education emphasized that it was of primary importance to first develop an understanding of students' affect, develop theoretical frameworks, and investigate relations between affect and achievement (Hannula et al. 2004; Zan et al. 2006). Mathematics educators thus did not prioritize intervention studies aimed at investigating the effectiveness of alternative teaching methods in the classroom.

Following this earlier neglect of intervention studies, Hannula-in his review of emotions in mathematical problem solving-referred to just one intervention study that addressed affect (Hannula 2015). We concur with Di Martino et al.'s (2015) call for intervention research and propose that a systematic evaluation of instructional interventions in the classroom should be considered an important next step in research in mathematics education.

\subsection{Theoretical grounding of intervention studies}

The existing interventions that aimed to modify emotions and motivation differ considerably in their theoretical foundations and contents. For example, treatments targeting emotional regulation comprise relaxation techniques, medical drugs, acquisition of competencies and learning skills, reappraisal, as well as selection, design, or modification of learning environments and tasks in affectively appropriate ways (Pekrun and Perry 2014). From the perspective of research on mathematics education, changing the design of learning environments and tasks is a particularly important way to change affect. Intervention studies manipulate the problems that are posed and/or the teaching methods that are used for these problems and examine the effects on affective and cognitive student outcomes.

One important requirement for intervention studies is that the treatment should be theoretically grounded. We illustrate possible theoretical groundings using the control-value theory of achievement emotions and the self-determination theory of motivation. As outlined earlier, the control-value theory posits that control and value appraisals function as proximal antecedents of achievement emotions (Pekrun 2006). Accordingly, treatments that aim to influence emotion are assumed to be powerful if they modify learners' control and value appraisals (see Figure 1). In self-determination theory (Ryan and Deci 2000), human motivation is hypothesized to emerge from experiences of competence, autonomy, and social relatedness. Thus, interventions that are aimed at improving motivation on the basis of 
this theory can aim to fulfill needs for competence, autonomy, or social relatedness in class, expecting that need fulfillment will influence motivation (see Figure 1).

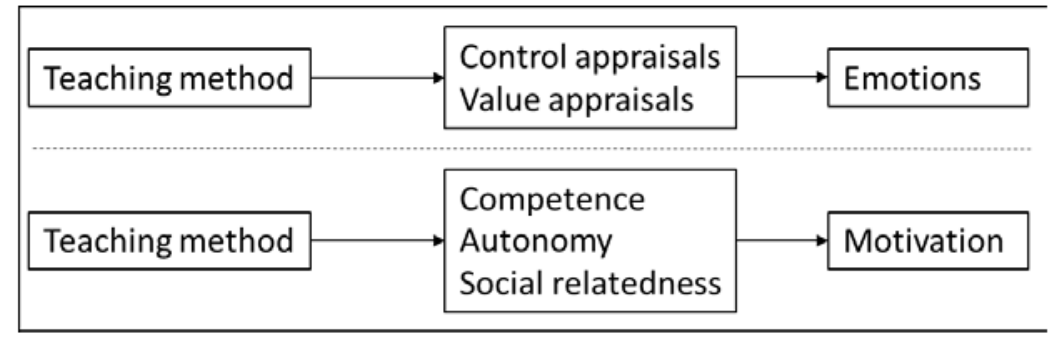

Figure 1. Effects of instruction on emotions and motivation assumed in the control-value theory of achievement emotions and the self-determination theory of motivation.

In the next three sections, we summarize intervention studies that targeted emotions and motivation, were implemented in the classroom, and were conducted under the guidance or participation of researchers from mathematics education (see the overview in Table 1). Our summary is based on a search for studies that were published or were referred to during the last ten years in the proceedings of the ERME- and PME-Conferences, Journal for Research in Mathematics Education, and Educational Studies in Mathematics. We also considered studies included in Lazowski and Hullemann's (2016) meta-analysis. There may be additional intervention studies not considered here, such as studies reported in unpublished dissertations or other journals. The studies that we identified investigated effects of treatments including (a) self-regulated and cooperative learning, (b) feedback, and (c) problems with multiple solutions (for motivational intervention studies in education more generally, see Lazowski and Hulleman 2016; Savelsbergh et al. 2016).

\subsection{Self-regulated and cooperative learning}

Effects of self-regulation and cooperative learning on emotions and motivation in mathematics were investigated in four intervention studies. Three of these studies used cooperative learning to implement self-regulation, and one study investigated cooperative learning in isolation.

Table 1 Overview of intervention studies investigating effects of teaching methods on students' affect

\begin{tabular}{|c|c|c|c|c|}
\hline $\begin{array}{l}\text { Teaching } \\
\text { method }\end{array}$ & Sample & Sub-domain & Results & Publications \\
\hline $\begin{array}{l}\text { Self-regulation } \\
\text { and cooperative } \\
\text { learning }\end{array}$ & $\begin{array}{l}\text { Primary } \\
\text { and lower } \\
\text { secondary } \\
\text { school }\end{array}$ & Problem solving & $\begin{array}{l}\text { Positive effects on } \\
\text { intrinsic goal } \\
\text { orientation and value. } \\
\text { No effects on self- } \\
\text { efficacy and extrinsic } \\
\text { goal orientation }\end{array}$ & $\begin{array}{l}\text { Marcou and } \\
\text { Lerman } 2007\end{array}$ \\
\hline $\begin{array}{l}\text { Self-regulation } \\
\text { and cooperative } \\
\text { learning }\end{array}$ & $\begin{array}{l}\text { Lower } \\
\text { secondary } \\
\text { school }\end{array}$ & Problem solving & $\begin{array}{l}\text { Positive effects on } \\
\text { motivation/volition, self- } \\
\text { reflection, self-efficacy, } \\
\text { and self-regulation. No } \\
\text { effects on goals and } \\
\text { learning strategies }\end{array}$ & $\begin{array}{l}\text { Perels et al. } \\
\text { 2005; Perels } \\
\text { et al. } 2007\end{array}$ \\
\hline $\begin{array}{l}\text { Self-regulation } \\
\text { and cooperative } \\
\text { learning }\end{array}$ & $\begin{array}{l}\text { Lower } \\
\text { secondary } \\
\text { school }\end{array}$ & $\begin{array}{l}\text { Modelling; } \\
\text { Pythagorean } \\
\text { theorem and } \\
\text { linear functions }\end{array}$ & $\begin{array}{l}\text { Positive effects on } \\
\text { enjoyment and interest. } \\
\text { No effects on values } \\
\text { and self-efficacy }\end{array}$ & $\begin{array}{l}\text { Schukajlow } \\
\text { et al. } 2012\end{array}$ \\
\hline Cooperative & Primary & Fractions & No effects on attitudes & Tarim and \\
\hline
\end{tabular}




\begin{tabular}{|c|c|c|c|c|}
\hline learning & school & & $\begin{array}{l}\text { (including items on } \\
\text { enjoyment, interest } \\
\text { etc.) }\end{array}$ & $\begin{array}{l}\text { Akdeniz } \\
2008\end{array}$ \\
\hline $\begin{array}{l}\text { Feedback } \\
\text { (process- } \\
\text { oriented vs. } \\
\text { social- } \\
\text { comparative) }\end{array}$ & $\begin{array}{l}\text { Lower } \\
\text { secondary } \\
\text { school }\end{array}$ & $\begin{array}{l}\text { Modelling and } \\
\text { intra-math. } \\
\text { problems; } \\
\text { Pythagorean } \\
\text { theorem and } \\
\text { linear equations }\end{array}$ & $\begin{array}{l}\text { Indirect effects on } \\
\text { interest, with } \\
\text { usefulness and } \\
\text { competence support as } \\
\text { intervening variables }\end{array}$ & $\begin{array}{l}\text { Rakoczy et } \\
\text { al. } 2013\end{array}$ \\
\hline $\begin{array}{l}\text { Word and intra- } \\
\text { mathematical } \\
\text { problems with } \\
\text { multiple } \\
\text { solutions }\end{array}$ & $\begin{array}{l}\text { Primary } \\
\text { school }\end{array}$ & $\begin{array}{l}\text { Word and intra- } \\
\text { math. problems }\end{array}$ & $\begin{array}{l}\text { No effects on } \\
\text { enjoyment, self- } \\
\text { confidence, mastery } \\
\text { goal orientation, or } \\
\text { effort }\end{array}$ & $\begin{array}{l}\text { Tuohilampi } \\
\text { et al. } 2015\end{array}$ \\
\hline $\begin{array}{l}\text { Real-world } \\
\text { problems with } \\
\text { multiple } \\
\text { solutions and } \\
\text { missing } \\
\text { information } \\
\end{array}$ & $\begin{array}{l}\text { Lower } \\
\text { secondary } \\
\text { school }\end{array}$ & $\begin{array}{l}\text { Modelling; } \\
\text { Pythagorean } \\
\text { theorem }\end{array}$ & $\begin{array}{l}\text { Positive effects on } \\
\text { interest, enjoyment, } \\
\text { boredom, autonomy, or } \\
\text { self-regulation. No } \\
\text { effects on self-efficacy } \\
\text { and value }\end{array}$ & $\begin{array}{l}\text { Schukajlow } \\
\text { and Krug } \\
2014 ; \\
\text { Schukajlow } \\
\text { and Rakoczy } \\
2016\end{array}$ \\
\hline $\begin{array}{l}\text { Multiple } \\
\text { mathematical } \\
\text { procedures for } \\
\text { real-world } \\
\text { problems }\end{array}$ & $\begin{array}{l}\text { Lower } \\
\text { secondary } \\
\text { school }\end{array}$ & $\begin{array}{l}\text { Modelling; linear } \\
\text { functions }\end{array}$ & $\begin{array}{l}\text { Positive effects on } \\
\text { experience of } \\
\text { competence. No } \\
\text { effects on interest, } \\
\text { enjoyment, boredom, } \\
\text { or self-regulation }\end{array}$ & $\begin{array}{l}\text { Achmetli et } \\
\text { al. 2015; } \\
\text { Achmetli and } \\
\text { Schukajlow } \\
2017 ; \\
\text { Schukajlow } \\
\text { and Achmetli } \\
2017\end{array}$ \\
\hline
\end{tabular}

One study did not find any benefits of cooperative learning environments (Tarim and Akdeniz 2008), whereas three studies partially confirmed positive effects of teaching for selfregulation-which included a cooperative learning environment as an important part-on affective variables (Marcou and Lerman 2007; Perels et al. 2007; Schukajlow et al. 2012). In the quasi-experimental study carried out by Tarim and Akdeniz (2008), a cooperative teaching method was applied to teach fourth-graders. In the control group, the same learning materials were used, but teachers were asked to employ their regular teaching methods, which included unit presentation, individual practice activities, and quizzes. Contrary to researchers' expectations, there were no differences between the groups in students' attitudes toward mathematics after 14 weeks of treatment. One possible limitation of this study, however, was a lack of treatment fidelity. It is possible that teachers in the control group also practiced cooperative teaching methods, which could explain the lack of treatment effects.

In the study by Marcou and Lerman (2007), fourth-, fifth-, and sixth-graders learned to regulate their problem solving in thirty 40-minute lessons taught over a period of seven months. The training program was focused on training students to use strategies and included a combination of cooperative learning and individual work. A control group did not receive any instruction. At posttest, the experimental group (15 classes) reported higher task values and intrinsic goal orientation than the control group (13 classes). Self-efficacy did not differ between the groups.

Perels et al. (2005) investigated how self-regulation training, which included a problemsolving training component, affected students' motivation. In the experimental condition, students worked for a considerable amount of time in groups, whereas no rules for the use of 
cooperative learning were provided in the control group. Positive effects on motivation/volition, self-reflection, self-efficacy, and self-regulation but no effects on goals and learning strategies, were found after six 90 -minute training sessions.

In the study by Schukajlow et al. (2012), a self-regulated teaching method using modelling problems was compared with teacher-directed instruction. In the experimental group, students spent ten lessons working according to a specific cooperation script with a focus on self- and socially regulated problem solving ("co-construction" of solutions) in learning groups. Students in two control conditions either received direct instruction by the teacher or worked individually on the same problems. Treatment fidelity in both conditions was confirmed by questionnaires, videos, and observations in the classroom. Students in the experimental group reported greater enjoyment, greater interest, and lower boredom but similar task-specific values and self-efficacy expectations after the teaching unit.

\subsection{Feedback on achievement}

Recently, Rakoczy at al. (2013) investigated (1) whether process-oriented feedback in mathematics (i.e., feedback to learners regarding their strengths and weaknesses in the cognitive operations applied and strategies for how to continue) leads to more interest and better achievement compared with social-comparison feedback; (2) whether students' perceptions of feedback in terms of its usefulness and support of competence mediates these effects; and (3) whether the impact of feedback is moderated by students' masteryapproach goal orientation. To answer these questions, 146 ninth-grade students in the intermediate secondary school track in Germany (Realschule) were randomly assigned to either a condition with process-oriented feedback or with social-comparison feedback. While process-oriented feedback combined the feedback characteristics that had been shown to promote learning in previous studies, social-comparison feedback represented the feedback common in many schools today. Results of path analyses revealed (1) no significant total effects of feedback on interest and achievement but (2) indirect effects on interest mediated by perceived competence support and usefulness and on achievement mediated by perceived usefulness, as well as (3) a moderator effect of mastery-approach goal orientation on the impact of feedback on perceived usefulness. That is, process-oriented feedback led to students' better achievement and greater interest when it was perceived as helpful and supportive of competence. Particularly students who were strongly oriented toward learning goals benefitted from process-oriented feedback.

\subsection{Problems with multiple solutions}

Furthermore, an intervention study was carried out to investigate the emotional and motivational effects of prompting students to construct multiple solutions to real-world problems with missing information (Schukajlow and Krug 2014; Schukajlow and Rakoczy 2016; Schukajlow and Krug 2012). 144 ninth-graders from six lower secondary school classes were assigned to an experimental or control condition. They were instructed to find two alternative solutions (experimental condition) or only one single solution (control condition) to six similar problems. After a five-lesson teaching unit, students' interest and self-regulation were higher in the experimental than in the control group. Furthermore, prompting students to find two solutions enhanced their enjoyment and reduced boredom; this effect was mediated by the number of solutions developed. Moreover, the number of solutions developed, enjoyment, and experiences of competence (but not autonomy and boredom) mediated the effects of the treatment on interest. No differences between groups were found for value appraisals.

However, most of these positive effects were not confirmed for another type of multiple solutions, namely, multiple solutions for real-world problems by applying different 
mathematical procedures. A follow-up study investigated how prompting students to apply multiple mathematical procedures influenced affect. In four 45-minute lessons, 307 lower secondary school students applied one or two procedures to solve real-world problems. There were no effects on interest, enjoyment, boredom, or self-regulation (Achmetli et al. 2014; Achmetli and Schukajlow 2017; Schukajlow and Achmetli 2017). A similar result was found in a long-term study for fostering students to construct multiple solutions by Tuohilampi et al. (2015). In the experimental group, students solved one word or intra-mathematical problem in a month during three years (from third grade to fifth grade). Prompting students to find multiple solutions for word or intra-mathematical problems did not affect students' enjoyment, self-confidence or effort.

This result underscores the importance of specific features of mathematical problems and related teaching methods for investigating treatment effects on affective variables. Whereas prompting students to develop multiple solutions by making individual assumptions about information missing in the task improved a number of affective variables, asking students to apply two procedures to the same problem did not have these beneficial effects.

\subsection{Summary and open questions}

More than seventy years after Pólya's comments on the role of affect in mathematical problem solving, considerable efforts have been made to better understand the role of affect for learning of mathematics. Simplistic views of affect in terms of dichotomous conceptions of positive versus negative affect have been replaced by more differentiated accounts of different types and dimensions of emotions and motivation. Researchers have also developed well-grounded theories to address the antecedents and outcomes of students' emotions and motivation and have successfully tested the validity of these theories in empirical studies using various qualitative and quantitative methodologies. Parents', teachers', and students' perceptions of affective variables have been investigated, which has contributes to the understanding of the joint impact of these actors on students' affective development. Furthermore, more recently, researchers have begun to conduct intervention studies in the classroom to examine the effects of instruction in mathematics on students' learning- and achievement-related emotions and motivation in this domain.

However, the evidence produced so far has appeared to generate more new questions than it can answer. Findings on mathematics-related emotions and motivation are still too scarce to derive firm conclusions based on cumulative, consistent evidence across studies. This lack of cumulative evidence, combined with a lack of conceptual clarity and the neglect of intervention research discussed earlier, has also made it difficult to derive evidence-based recommendations for practice. As such, we suggest that researchers continue with the work summarized herein, but we also suggest that they increase their research efforts to do the following (also see Pekrun and Linnenbrink-Garcia 2014b):

- integrate approaches from various disciplines that can contribute to research on emotions and motivation, such as mathematics education, educational psychology, educational and affective neuroscience, history of education, and economics of education;

- conduct studies that test theory-derived, explicit hypotheses based on such integrative approaches;

- investigate the relations between emotional and motivational constructs (e.g., enjoyment and the motivation to learn), between emotion/motivation and other affective variables (e.g., students' identities or beliefs about the nature of mathematics), and between emotion/motivation and cognitive variables (e.g., use of cognitive strategies and cognitive performance);

- simultaneously consider parents', teachers', and students' emotions and motivation; 
- design and test classroom instruction, tasks, and learning environments to foster students' emotions and motivation;

- include affective measures in intervention studies that primarily target cognitive outcomes;

- systematically combine quantitative and qualitative methodologies;

- integrate traditional interindividual research strategies with intraindividual analysis to make it possible to understand both differences between students and the individual affective development of each student (Murayama et al. in press);

- use experimental and longitudinal study designs that make it possible to examine causal relations as well as mediational processes, moderator effects, and multiple levels of variables (see Lauerman et al. 2017; Schütze et al. 2017);

- adapt novel assessment methods such as experience-sampling methods (Bieg et al. 2017), physiological analysis, and automatic coding of emotion expression;

- use analytical procedures to adequately model relations between variables within and across individual students and across multiple levels of educational institutions and systems, including statistical procedures to deal with missing data, such as multiple imputation or full information maximum likelihood (FIML) estimation (see e.g., Liebendörfer and Schukajlow 2017; Schütze et al. 2017) and to deal with multi-level data structures, such as hierarchical modeling or methods to correct parameter estimates for the effects of nestedness (see e.g., Bieg et al. 2017).

\section{References}

Achmetli, K., Krug, A., \& Schukajlow-Wasjutinski, S. (2015). Multiple Lösungsmöglichkeiten und ihre Nutzung beim mathematischen Modellieren. In G. Kaiser \& H.-W. Henn (Eds.), Werner Blum und seine Beiträge zum Modellieren im Mathematikunterricht (pp. 25-41, Realitätsbezüge im Mathematikunterricht). Wiesbaden: Springer Fachmedien.

Achmetli, K. \& Schukajlow, S. (2017, submitted for publication). Multiple solution, the experience of comptence and interest. In M. Hannula, G. Leder, F. Morselli, \& Z. Quao Ping (Eds.), Affect, beliefs and identity in mathematics education. Heidelberg, Germany: Springer.

Achmetli, K., Schukajlow, S., \& Krug, A. (2014). Effects of prompting students to use multiple solution methods while solving real-world problems on students' self-regulation. In C. Nicol, S. Oesterle, P. Liljedahl, \& D. Allan (Eds.), Proceedings of the Joint Meeting of PME 38 and PME-NA 36 (Vol. 2, pp. 1-8). Vancouver, Canada: PME.

Ahmed, W., van der Werf, G., Kuyper, H., \& Minnaert, A. (2013). Emotions, self-regulated learning, and achievement in mathematics: A growth curve analysis. Journal of Educational Psychology, 105(1), 150-161.

Bandura, A. (2003). Self-efficacy: The exercise of control (6. printing. ed.). New York: Freeman.

Battista, M., Smith, M. S., Boerst, T., Sutton, J., Confrey, J., White, D., et al. (2009). Research in mathematics education: Multiple methods for multiple uses. Journal for Research in Mathematics Education, 40(3), 216-240.

Beilock, S. L., Gunderson, E. A., Ramirez, G., \& Levine, S. C. (2010). Female teachers' math anxiety affects girls' math achievement. Proceedings of the National Academy of Sciences, 107, 1860-1863.

Beswick, K. (2011). Putting context in context: An examination of the evidence for the benefits of contextualised tasks. International Journal of Science and Mathematics Education, 9(2), 367-390, doi:10.1007/s10763-010-9270-z.

Bieg, M., Goetz, T., Sticca, F., Brunner, E., Becker, E., Morger, V., \& Hubbard, K. (2017). Teaching methods and their impact on students' emotions in mathematics: An experience-sampling approach. ZDM Mathematics Education, 49. doi:10.1007/s11858-017-0840-1 
Bikner-Ahsbahs, A. \& Halverscheid, S. (2014). Introduction to the Theory of Interest-Dense Situations (IDS). In Networking of theories as a research practice in mathematics education (pp. 97-113): Springer.

Blum, W. \& Leiss, D. (2007). How do students and teachers deal with mathematical modelling problems? The example sugarloaf and the DISUM project. In C. Haines, P. L. Galbraith, W. Blum, \& S. Khan (Eds.), Mathematical modelling (ICTMA 12): Education, engineering and economics (pp. 222-231). Chichester: Horwood.

Bong, M. \& Skaalvik, E. M. (2003). Academic self-concept and self-efficacy: How different are they really? Educational Psychology Review, 15, 1-40.

Brophy, J. E. \& Good, T. L. (1986). Teacher behavior and student achivement. In M. C. Wittrock (Ed.), Handbook of research on teaching (3rd ed., pp. 328-375). New York: Macmillan.

Buff, A., Reusser, K. \& Dinkelmann, I. (2017). Parental support and enjoyment of learning in mathematics: Does change in parental support predict change in enjoyment of learning? ZDM Mathematics Education, 49. doi:10.1007/s11858-016-0823-7

Cambria, J., Brandt, H., Nagengast, B., \& Trautwein, U. (2017). Training effects on teachers' feedback practice: The mediating function of feedback knowledge and the moderating role of self-efficacy. ZDM Mathematics Education, 49.

Campbell, R. J., Kyriakides, L., Muijs, R. D., \& Robinson, W. (2004). Effective teaching and values: Some implications for research and teacher appraisal. Oxford Review of Education, 30(4), 451-465.

Carmichael, C., Callingham, R., \& Watt, H. M. G. (2017). Classroom motivational environment influences on emotional and cognitive dimensions of student interest in mathematics. ZDM Mathematics Education, 49. doi:10.1007/s11858-016-0831-7

Chang, H., \& Beilock, S. L. (2016). The math anxiety-math performance link and its relation to individual and environmental factors: A review of current behavioral and psychophysiological research. Current Opinion in Behavioral Science, 10, 33-38.

Deci, E. L. \& Ryan, R. M. (2000). The "What" and "Why" of goal pursuits: Human needs and the selfdetermination of behavior. Psychological Inquiry, 11(4), 227-268.

Di Martino, P., Gómez-Chacón, I., Liljedahl, P., Morselli, F., Pantziara, M., \& Schukajlow, S. (2015). Introduction to the papers of TWG08: Affect and mathematical thinking. In K. Krainer, \& N. Vondrová (Eds.), Proceedings of the of the Ninth Congress of the European Society for Research in Mathematics Education (pp. 1104-1108). Prague, Szech Republic: Charles University in Prague, Faculty of Education and ERME.

Dweck, C. S. \& Elliott, S. (1983). Achievement motivation. In P. Mussen (Ed.), Handbook of child psychology: Socialization, personality, and social development (pp. 643-691). NY: Wiley.

Eccles (Parson), J., Adler, T. F., Futterman, R., Goff, S. B., Kaczala, C. M., Meece, J. L., et al. (1983). Expectancies, values, and academic behaviors. In J. T. Spence (Ed.), Achievement and achievement motivation (pp. 75-146). San Francisco: Freeman.

Eccles, J. S. \& Wigfield, A. (2002). Motivational beliefs, values, and goals. Annual Review of Psychology, 53, 109-132.

Ekman, P. (1992). An argument for basic emotions. Cognition \& Emotion, 6(3-4), 169-200.

Feng, S.-L. \& Tuan, H.-L. (2005). Using ARCS model to promote 11th graders' motivation and achievement in learning about acids and bases. International Journal of Science and Mathematics Education, 3(3), 463-484.

Frenzel, A. C. (2014). Teacher emotions. In R. Pekrun \& E. A. Linnenbrink (Eds.), International handbook of emotions in education (pp. 494-519). New York, NY: Routledge.

Frenzel, A. C., Goetz, T., Ludtke, O., Pekrun, R., \& Sutton, R. E. (2009). Emotional transmission in the classroom: Exploring the relationship between teacher and student enjoyment. Journal of Educational Psychology, 101(3), 705-716.

Frenzel, A. C., Pekrun, R., Dicke, A.-L., \& Goetz, T. (2012). Beyond quantitative decline: Conceptual shifts in adolescents' development of interest in mathematics. Developmental Psychology, 48(4), 1069-1082. 
Gläser-Zikuda, M., Fuß, S., Laukenmann, M., Metz, K., \& Randler, C. (2005). Promoting students' emotions and achievement--Instructional design and evaluation of the ECOLE-approach. Learning and Instruction, 15, 481-495.

Goetz, T., Frenzel, A. C., Pekrun, R., Hall, N. C., \& Lüdtke, O. (2007). Between- and withindomain relations of students' academic emotions. Journal of Educational Psychology, 99, 715-733.

Goetz, T., Lüdtke, O., Nett, U. E., Keller, M. M., \& Lipnevich, A. A. (2013). Characteristics of teaching and students' emotions in the classroom: Investigating differences across domains. Contemporary Educational Psychology, 38(4), 383-394.

Goldin, G. A. (2000). Affective pathways and representation in mathematical problem solving. Mathematical Thinking and Learning, 2(3), 209-219.

Gómez-Chacón, I. (2017). Emotions and heuristics: The state of perplexity in mathematics. ZDM Mathematics Education, 49.

Grigutsch, S., Raatz, U., \& Törner, G. (1998). Einstellungen gegenüber Mathematik bei Mathematiklehrern. Journal für Mathematikdidaktik, 98, 3-45.

Guthrie, J. T., Wigfield, A., Humenick, N. H., Perencevich, K. C., Taboada, A., \& Barbosa, P. (2006). Influences of stimulating tasks on reading motivation and comprehension. Journal of Educational Research, 99(4), 232-247.

Hannula, M. S. (2006). Motivation in mathematics: Goals reflected in emotions. Educational Studies in Mathematics, 63, 165-178.

Hannula, M. S. (2015). Emotions in Problem Solving. In S. J. Cho (Ed.), Selected Regular Lectures from the 12th International Congress on Mathematical Education (pp. 269288): Springer International Publishing.

Hannula, M. S., Evans, J., Philippou, G., \& Zan, R. (2004). Affect in Mathematics Education-Exploring Theoretical Frameworks. Research Forum. International Group for the Psychology of Mathematics Education.

Hattie, J. (2009). Visible learning: A synthesis of meta-analyses relating to achievement. London: Routledge.

Hidi, S. \& Renninger, K. A. (2006). The four phase model of interest development. Educational Psychologist, 41(2), 111-127.

Hiebert, J., Gallimore, R., Garnier, H., Givvin, K. B., Hollingsworth, H., Jacobs, J., et al. (2003). Teaching mathematics in seven countries. Results from the TIMSS 1999 video study. Washington, DC: NCES.

Jacobs, J. E., Lanza, S., Osgood, D. W., Eccles, J. S., \& Wigfield, A. (2002). Changes in children's self-competence and values: Gender and domain differences across grades one through twelve. Child Development, 73(2), 509-527.

Jacob, B., Frenzel, A. C., \& Stephens, E. G. (2017). Good teaching feels good--but what is "good teaching"? Exploring teachers' definitions of teaching success in mathematics. ZDM Mathematics Education, 49.

Klieme, E., Lipowsky, F., Rakoczy, K., \& Ratzka, N. (2006). Qualitätsdimensionen und Wirksamkeit von Mathematikunterricht. Theoretische Grundlagen und ausgewählte Ergebnisse des Projekts „Pythagoras“. In M. Prenzel, \& L. Allolio-Nacke (Eds.), Untersuchungen zur Bildungsqualität von Schule. Abschlussbericht des DFGSchwerpunktprogramms (pp. 127-146). Münster: Waxmann.

Köller, O., Baumert, J., \& Schnabel, K. (2001). Does interest matter? The relationship between academic interest and achievement in mathematics. Journal for Research in Mathematics Education, 32(5), 448 - 470

Krapp, A. (2002). Structural and dynamic aspects of interest development: Theoretical considerations from an ontogenetic perspective. Learning and Instruction, 12, 383409.

Krapp, A. (2005). Basic needs and the development of interest and intrinsic motivational orientations. Learning and Instruction, 15, 381-395.

Kunter, M. \& Baumert, J. (2006). Who is the expert? Construct and criteria validity of student and teacher ratings of instruction. Learning Environments Research, 9(3), 231-251.

Larson, R. W., \& Richards, M. H. (1991). Boredom in the middle school years. Blaming schools versus blaming students. American Journal of Education, 99(4), 418-443. 
Lauermann, F., Eccles, J. S., \& Pekrun, R. (2017). Why do children worry about their academic achievement? An expectancy-value perspective on elementary students' worries about their mathematics and reading performance. ZDM Mathematics Education, 49. doi:10.1007/s11858-017-0832-1

Lazowski, R. A. \& Hulleman, C. S. (2016). Motivation interventions in education: A metaanalytic review. Review of Educational Research, 86, 602-640.

Lichtenfeld, S., Pekrun, R., Stupnisky, R. H., Reiss, K., \& Murayama, K. (2012). Measuring students' emotions in the early years: The Achievement Emotions QuestionnaireElementary School (AEQ-ES). Learning and Individual Differences, 22(2), 190-201.

Liebendörfer, M., \& Schukajlow, S. (2017). Interest development during the first year at university: Do mathematical beliefs predict interest in mathematics? ZDM Mathematics Education, 49. doi:10.1007/s11858-016-0827-3

Lipowsky, F., Rakoczy, K., Pauli, C., Drollinger-Vetter, B., Klieme, E., \& Reusser, K. (2009). Quality of geometry instruction and its short-term impact on students' understanding of the Pythagorean Theorem. Learning and Instruction, 19(6), 527-537.

Marcou, A. \& Lerman, S. (2007). Changes in students' motivational beliefs and performance in a self-regulated mathematical problem-solving environment. In CERME 5, Cyprus, (pp. 288-297).

Marsh, H. W., Pekrun, R., Lichtenfeld, S., Guo, J., Arens, A. K., \& Murayama, K. (2016). Breaking the double-edged sword of effort/trying hard: Developmental equilibrium and longitudinal relations among effort, achievement, and academic self-concept. Developmental Psychology, 52, 1273-1290.

McLeod, D. B. (1992). Research on affect in mathematics education: A reconceptualization. In D. A. Grouws (Ed.), Handbook of research on mathematics, teaching and learning (pp. 575-596). New York: Macmillan.

Murayama, K., Goetz, T., Malmberg, L.-E., Pekrun, R., Tanaka, A., \& Martin, A. J. (in press). Within-person analysis in educational psychology: Importance and illustrations. British Journal of Educational Psychology.

Nett, U. E., Goetz, T., \& Hall, N. C. (2011). Coping with boredom in school: An experience sampling perspective. Contemporary Educational Psychology, 36, 49-59.

Oatley, K. \& Johnson-Laird, P. N. (1987). Towards a cognitive theory of emotions. Cognition and emotion, 1(1), 29-50.

Pantziara, M. \& Philippou, G. N. (2015). Students' motivation in the mathematics classroom. Revealing causes and consequences. International Journal of Science and Mathematics Education, 13(2), 385-411.

Pauli, C. \& Reusser, K. (2006). Von international vergleichenden Video Surveys zur videobasierten Unterrichtsforschung und -entwicklung. Zeitschrift für Pädagogik, 52(6), 774-798.

Pekrun, R. (1993). Facets of students' academic motivation: A longitudinal expectancy-value approach. In M. Maehr \& P. Pintrich (Eds.), Advances in Motivation and Achievement (Vol. 8, pp. 139-189). Greenwich, CT: JAI Press.

Pekrun, R. (2006). The control-value theory of achievement emotions: Assumptions, corollaries, and implications for educational research and practice. Educational Psychology Review, 18, 315-341.

Pekrun, R., Goetz, T., Daniels, L. M., Stupnisky, R. H., \& Perry, R. P. (2010). Boredom in achievement settings: Exploring control-value antecedents and performance outcomes of a neglected emotion. Journal of Educational Psychology, 102(3), 531549.

Pekrun, R., Goetz, T., Frenzel, A. C., Barchfeld, P., \& Perry, R. P. (2011). Measuring emotions in students' learning and performance: The Achievement Emotions Questionnaire (AEQ). Contemporary Educational Psychology, 36, 36-48.

Pekrun, R., vom Hofe, R., Blum, W., Frenzel, A. C., Goetz, T. \& Wartha, S. (2007). Development of mathematical competencies in adolescence: The PALMA longitudinal study. In M. Prenzel (Ed.), Studies on the educational quality of schools (pp. 17-37). Münster, Germany: Waxmann. 
Pekrun, R., Goetz, T., Titz, W., \& Perry, R. P. (2002). Academic emotions in students' selfregulated learning and achievement: A program of qualitative and quantitative research. Educational Psychologist, 37(2), 91-105.

Pekrun, R., Hall, N. C., Goetz, T., \& Perry, R. P. (2014). Boredom and academic achievement: Testing a model of reciprocal causation. Journal of Educational Psychology, 106(3), 696.

Pekrun, R., Lichtenfeld, S., Marsh, H. W., Murayama, K., \& Goetz, T. (2017). Achievement emotions and academic performance: Longitudinal models of reciprocal effects. Child Development. Published online first, doi: 10.1111/cdev12704

Pekrun, R. \& Linnenbrink-Garcia, L. (2014a). Introduction to emotions in education. In R. Pekrun, \& L. Linnenbrink-Garcia (Eds.), International handbook of emotions in education (pp. 1-10). New York: Taylor \& Francis.

Pekrun, R. \& Linnenbrink-Garcia, L. (2014b). Conclusions and future directions. In R. Pekrun \& L. Linnenbrink-Garcia (Eds.), International handbook of emotions in education (pp. 659-675). New York: Taylor \& Francis.

Pekrun, R. \& Perry, R. P. (2014). Control-value theory of achievement emotions. International handbook of emotions in education, 120-141.

Perels, F., Gürtler, T., \& Schmitz, B. (2005). Training of self-regulatory and problem-solving competence. Learning and Instruction, 15, 123-139.

Perels, F., Otto, B., Schmitz, B., \& Bruder, R. (2007). Evaluation of a training programme to improve mathematical as well as self-regulatory competences. In M. Prenzel, \& PISAKonsortium Deutschland (Eds.), Studies on the educational quality of schools (pp. 197-219). Münster: Waxmann.

Pintrich, P. R. (1991). Editor's comment. Educational Psychologist, 26(3-4), 199-205.

Pólya, G. (1945). How to solve it: A new aspect of mathematical method. New Jersey: Princeton University Press.

Rakoczy, K. (2008). Motivationsunterstützung im Mathematikunterricht--Unterricht aus der Perspektive von Lernenden und Beobachtern. Münster: Waxmann.

Rakoczy, K., Harks, B., Klieme, E., Blum, W., \& Hochweber, J. (2013). Written feedback in mathematics: Mediated by students' perception, moderated by goal orientation. Learning and Instruction, 27, 63-73.

Rakoczy, K., Klieme, E., Drollinger-Vetter, B., Lipowsky, F., Pauli, C., \& Reusser, K. (2007). Structure as a quality feature in mathematics instruction: Cognitive and motivational effects of a structured organisation of the learning environment vs. a structured presentation of learning content. In P. M. (Ed.), Studies on the educational quality of schools. The final report on the DFG Priority Programme (pp. 101-120). Münster: Waxmann.

Rellensmann, J. \& Schukajlow, S. (2017). Does students' interest in a mathematical problem depend on the problem's connection to reality? An analysis of students' interest and pre-service teachers' judgments of students' interest in problems with and without a connection to reality. ZDM Mathematics Education, 49, doi:10.1007/s11858-0160819-3.

Renninger, K. A., Shumar, W., Barab, S., Kling, R., \& Gray, J. (2004). The centrality of culture and community to participant learning at and with The Math Forum. Designing for virtual communities in the service of learning, 181-209.

Reuman, D., Maclver, D., Eccles, J. S., \& Wigfield, A. (1987). Changes in students' mathematics motivation and behavior at the transition to junior high school. In Annual meeting of the American Educational Research Association. Washington,

DC.Robinson, D. H., Levin, J. R., Thomas, G. D., Pituch, K. A., \& Vaughn, S. (2007). The incidence of "causal" statements in teaching-and-learning research journals. American Educational Research Journal, 44(2), 400-413.

Ruthig, J. C., Perry, R. P., Hall, N. C., \& Hladkyj, S. (2004). Optimism and attributional retraining: Longitudinal effects on academic achievement, test anxiety, and voluntary course withdrawal in college students. Journal of Applied Social Psychology, 34(4), 709-730.

Ryan, R. M. (2012). The Oxford handbook of human motivation: Oxford University Press. 
Ryan, R. M. \& Deci, E. L. (2000). Self-determination theory and the facilitation of intrinsic motivation, social development, and well-being. American Psychologist, 55, 68-78.

Ryan, R. M. \& Deci, E. L. (2002). Overview of self-determination theory: An organismicdialectical perspective. In E. L. Deci \& A. M. Ryan (Eds.), Handbook of selfdetermination research (pp. 3-33). Rochester: University Press.

Savelsbergh, E. R., Prins, G. T., Rietbergen, C., Fechner, S., Vaessen, B. E., Draijer, J. M., et al. (2016). Effects of innovative science and mathematics teaching on student attitudes and achievement: A meta-analytic study. Educational Research Review, 19, 158-172.

Scherer, K., Schorr, A., \& Johnstone, T. (2001). Appraisal processes in emotion: Theory, methods, research: Oxford University Press.

Scherer, K., Shuman, V., Fontaine, J., \& Soriano, C. (2013). The GRID meets the Wheel: Assessing emotional feeling via self-report. Components of emotional meaning: $A$ sourcebook, 281-298.

Schukajlow, S. (2015). Is boredom important for students' performance? In K. Krainer, \& N. Vondrová (Eds.), Proceedings of the Ninth Congress of the European Society for Research in Mathematics Education (pp. 1273-1279). Prague, Szech Republic: Charles University in Prague, Faculty of Education and ERME.

Schukajlow, S. \& Achmetli, K. (2017, accepted). Multiple solutions for real-world problems and students' enjoyment, and boredom. In Proceedings of the Ninth Congress of the European Society for Research in Mathematics Education.

Schukajlow, S. \& Krug, A. (2012). Effects of treating multiple solutions on students' selfregulation, self-efficacy and value. In T. Y. Tso (Ed.), Proceedings of the 36th Conference of the International Group for the Psychology of Mathematics Education (Vol. 4, pp. 59-66). Taipei, Taiwan: PME.

Schukajlow, S. \& Krug, A. (2014). Do multiple solutions matter? Prompting multiple solutions, interest, competence, and autonomy. Journal for Research in Mathematics Education, 45(4), 497-533.

Schukajlow, S., Leiss, D., Pekrun, R., Blum, W., Müller, M., \& Messner, R. (2012). Teaching methods for modelling problems and students' task-specific enjoyment, value, interest and self-efficacy expectations. Educational Studies in Mathematics, 79, 215-237.

Schukajlow, S., \& Rakoczy, K. (2016). The power of emotions: Can enjoyment and boredom explain the impact of individual preconditions and teaching methods on interest and performance in mathematics? Learning and Instruction, 44, 117-127.

Schunk, D. H. \& Meece, J. L. (2006). Self-efficacy development in adolescence. In F. Pajares, \& T. Urdan (Eds.), Self-efficacy beliefs of adolescents (pp. 71-96). Greenwich, CT: Information Age.

Schutz, P. A. \& Lanehart, S. L. (2002). Introduction: Emotions in education. Educational Psychologist, 37(2), 67-68, doi:10.1207/S15326985EP3702_1.

Schütze, B., Rakoczy, K., Klieme, E., Besser, M., \& Leiss, D. (2017). Training effects on teachers' feedback practice: The mediating function of feedback knowledge and the moderating role of self-efficacy. ZDM Mathematics Education, 49.

Seidel, T. \& Shavelson, R. J. (2007). Teaching effectiveness research in the past decade: The role of theory and research design in disentangling meta-analysis results. Review of Educational Research, 77(4), 454-499.

Sherman, D. K., Hartson, K. A., Binning, K. R., Purdie-Vaughns, V., Garcia, J., TaborskyBarba, S., et al. (2013). Deflecting the trajectory and changing the narrative: How self-affirmation affects academic performance and motivation under identity threat. Journal of Personality and Social Psychology, 104(4), 591.

Shuman, V. \& Scherer, K. R. (2014). Concepts and structures of emotions. In R. Pekrun \& L. Linnenbrink-Garcia (Eds.), International handbook of emotions in education (pp. 1335). New York: Taylor \& Francis.

Street, K. E. S., Malmberg, L.-E., \& Stylianides, G. J. (2017). Level, strength, and facetspecific self-efficacy in mathematics test performance. ZDM Mathematics Education, 49. doi:10.1007/s11858-017-0833-0 
Stylianides, A. J. \& Stylianides, G. J. (2014). Impacting positively on students' mathematical problem solving beliefs: An instructional intervention of short duration. The Journal of Mathematical Behavior, 33, 8-29.

Tarim, K. \& Akdeniz, F. (2008). The effects of cooperative learning on Turkish elementary students' mathematics achievement and attitude towards mathematics using TAI and STAD methods. Educational Studies in Mathematics, 67(1), 77-91.

Tornare, E., Czajkowski, N. O., \& Pons, F. (2015). Children's emotions in math problem solving situations: Contributions of self-concept, metacognitive experiences, and performance. Learning and Instruction, 39, 88-96.

Toerner, G. \& Arzarello, F. (2012). Grading mathematics education research journals. In L. Di Visio \& V. Munoz (Eds.), Newsletter of the European mathematical society (pp. 5456).

Tulis, M. \& Ainley, M. (2011). Interest, enjoyment and pride after failure experiences? Predictors of students' state-emotions after success and failure during learning in mathematics. Educational Psychology: An International Journal of Experimental Educational Psychology, 31(7), 779-807.

Tuohilampi, L., Näveri, L., \& Laine, A. (2015). The restricted yet crucial impact of an intervention on pupils' mathematics-related affect. In N. Vondrova \& J. Novotna (Eds.), Ninth Congress of the European Society for Research in Mathematics Education (pp. 1287-1293). Prague: Charles University of Prague.

Ufer, S., Rach, S., \& Kosiol, T. (2017). Interest in mathematics= interest in mathematics? What general measures of interest reflect when the object of interest changes. ZDM Mathematics Education, 49. doi:10.1007/s11858-016-0828-2

Vierhaus, M., Lohaus, A., \& Wild, E. (2016). The development of achievement emotions and coping/emotion regulation from primary to secondary school. Learning and Instruction, 42, 12-21.

Volet, S. (2001). Understanding learning and motivation in context: A multi-dimensional and multi-level cognitive-situative perspective. In S. Volet \& S. Järvelä (Eds.), Motivation in learning contexts: Theoretical advances and methodological implications (pp. 5782). Elmsford, NY, US: Pergamon Press.

Vollmeyer, R., \& Rheinberg, F. (2005). A surprising effect of feedback on learning. Learning and Instruction, 15(6), 589-602.

Weiner, B. (1985). An attributional theory of achievement motivation and emotion. Psychological Review, 92(4), 548.

Wigfield, A. \& Eccles, J. S. (2000). Expectancy-Value Theory of Achievement Motivation. Contemporary Educational Psychology, 25, 68-81.

Wigfield, A. \& Meece, J. L. (1988). Math anxiety in elementary and secondary school students. Journal of Educational Psychology, 80(2), 210.

Winberg, T. M., Hellgren, J., \& Palm, T. (2014). Stimulating positive emotional experiences in mathematics learning: Influence of situational and personal factors. European Journal of Psychology of Education, 29(4), 673-691.

Zan, R., Brown, L., Evans, J., \& Hannula, M. S. (2006). Affect in mathematics education: An introduction. Educational Studies in Mathematics, 63(2), 113-122. 